\title{
INCIDENCE OF BREAST CANCER AND ROLE OF ENVIROMMENTAL PERSISTENT ORGANOCHLORINE POLLUTANTS (ANALYSIS OF LITERARY DATA]
}

Chernychenko I.O., Balenko N.V., Lytvychenko O.M., Babii V.F., Glavachek D.O., Kondratenko O.Ye.

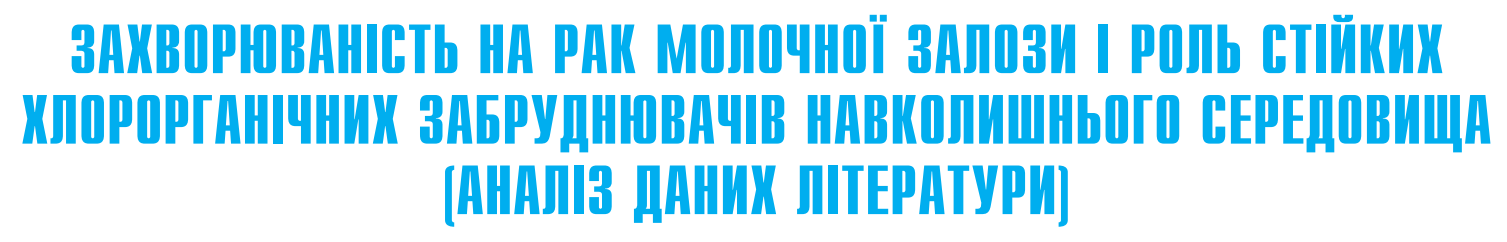

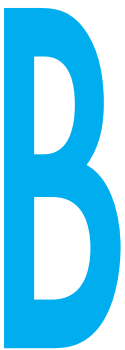

ЧЕРНИЧЕНКО І.О., БАЛЕНКО Н.В, ЛИТВИЧЕНКО О.М., БАБІЙ В.Ф., ГЛАВАЧЕК Д.О. КОНДРАТЕНКО О.Є.

ДУ “Інститут громадського здоров'я ім. О.М. Марзєєва НАМН України", м. Київ, Україна

Ключові слова: рак молочної залози, захворюваність, стійкі хлорорганічні забруднення. останні десятиріччя у проблемі профілактики онкозахворюваності все більшої актуалізації набуває напрямок, пов'язаний 3 захворюваністю населення на гормонозалежні злоякісні пухлини - рак молочної залози, матки, яєчників у жінок, рак передміхурової залози, тестикулярний рак у чоловіків, а також рак щитоподібної залози [1-5]. Це пояснюється, з одного боку, високою частотою і тенденцією до селективного зростання захворюваності на ці види пухлин в усьому світі, а 3 іншого - стабільним зростанням кількості ідентифікованих хімічних сполук, які чинять шкідливий вплив на ендокринну систему, та збільшенням кількості доводів їхнього зв'язку з розвитком ендокриннопов'язаних пухлин.

Речовини з таким характером дії на організм отримали назву «Endocrine disrupting chemicals», тобто «хімічні руйнівники ендокринної системи» (XPEC).
Мета даної роботи - вивчення стану наукових досліджень 3 захворюваності на рак молочної залози (РМЗ) і ролі стійких хлорорганічних забруднювачів навколишнього середовища в її формуванні, які належать до XPEC.

Матеріали та методи. Аналіз джерел літератури з експериментальних та епідеміологічних досліджень 3 різних аспектів РМЗ (захворюваність, поширеність, фактори ризику, вплив хімічних забруднювачів довкілля, особливості біоефектів та можливі механізми реалізації канцерогенезу тощо). Використано метод теоретичного аналізу.

Результати аналізу та обговорення. Згідно 3 даними ВОО3/OOH [1] та Міжнародного агентства 3 вивчення раку (MABP), OOH [2], РМЗ є найбільш частою формою раку у жінок, що діагностується у 140 країнах світу, і найбільш частою причиною смерті через рак у 110 країнах світу. Зростання
ЗАБОЛЕВАЕМОСТЬ РАКОМ МОЛОЧНОЙ ЖЕЛЕЗЫ И РОЛЬ СТОЙКИХ ХЛОРОРГАНИЧЕСКИХ ЗАГРЯЗНИТЕЛЕЙ ОКРУЖАЮЩЕЙ СРЕДЫ (АНАЛИЗ ДАННЫХ ЛИТЕРАТУРЫ)

Черниченко И.А., Баленко Н.В, Литвиченко О.Н., Бабий В.Ф., Главачек Д.А., Кондратенко E.E.

ГУ "Институт общественного здоровья имени А.Н. Марзеева НАМН Украины", г. Киев, Украина

Обоснование. В настоящее время рак молочной железы стал наиболее распространенным гормонозависимым раком среди женщин во всем мире. Этиология рака молочной железы является многофакторной. Один из предполагаемых факторов увеличения заболеваемости раком молочной железы - химические вещества окружающей среды, повреждающие эндокринную систему - эндокринные дизрапторы (ЭД). К ним относятся, в частности, стойкие хлорорганические загрязнители окружающей среды.

Цель. Мы проанализировали литературные данные, касающиеся роли некоторых стойких хлорорганических химических веществ, таких как
ДДТ, диоксины и полихлорированные дифенилы в формировании заболеваемости раком молочной железы.

Результаты. Анализ эпидемиологических исследований, несмотря на их небольшое количество, четко демонстрирует взаимосвязь воздействия исследуемых ЭД с повышенным риском развития рака молочной железы у женщин. При этом было установлено, что воздействие ЭД в критические периоды времени (в утробном, неонатальном и пубертатном периодах), когда гормоны действуют на дифференцировку клеток и развитие тканей, может нарушать развитие тканей молочной железы и приводить к появлению рака молочной железы у взрослых женщин. Результаты анализа подтверждают актуальность проблемы и необходимость дальнейших исследований и решения вопросов защиты населения от вредного воздействия ЭД.

Ключевые слова: рак молочной железы, заболеваемость, стойкие хлорорганические загрязнения.

() Черниченко І.О., Баленко Н.В, Литвиченко О.М., Бабій В.Ф., Главачек Д.О., Кондратенко О.Є. СТАТТЯ, 2019. 
захворюваності спостерігається майже в усіх індустріально розвинутих країнах. Загалом, збільшення числа хворих на РМЗ спостерігається 3 40-х років минулого століття і нині швидко зростає у країнах, що розвиваються. Щорічно у світі реєструється понад 1 млн. нових випадків РМЗ. 2012 року було зареєстровано 1,7 млн. нових випадків (25\% від усіх випадків раку у жінок) та 0,5 млн. смертей (15\% усіх смертей жінок через рак). Найвищі рівні захворюваності за стандартизованими показниками спостерігаються у Західній Європі, найнижчі - у Східній Азії. Близько 43\% нових випадків PM3 та 34\% смертей через РМ3 реєструються у країнах Європи та Північної Америки. Рівень смертності у різних регіонах світу відрізняється у 2-5 разів, хоча при цьому у більш розвинутих країнах є суттєво нижчим. Незважаючи на зростання захворюваності у більшості регіонів світу у найбільш розвинутих країнах вона досягла максимального рівня і в останні десятиріччя дещо знизилася. Знизилася також смертність через РМЗ у цих країнах, що пов'язують з покращанням діагностики та лікування [6].

Згідно 3 повідомленням Rodgers K.M. et all [6] рівень захворюваності на РМЗ у США стабільний, проте $є$ найвищим у світі. При цьому пояснюється, що певний внесок у захворюваність дає хімічне забруднення навколишнього середовища.

Аналіз трендів захворюваності на рак різних локалізацій, проведений у Франції за даними канцер-реєстру, показав селективне зростання після 1980-х років РМЗ, раку простати, яєчок і щитоподібної залози. Причому зростання частоти РМЗ тривало до 2005 року, потім почало знижуватися, що, на думку автора, пов'язане зі зменшенням використання естрогенних гормонів для лікування, як це спостерігалося у США [3].

РМЗ є мультифакторним захворюванням [1, 2, 4, 6]. До факторів ризику РМЗ належать вік менархе і менопаузи, спадкова чутливість, відсутність в анамнезі пологів, збільшення віку (після 30 років) народження першої дитини тощо. Цьому сприяють також певні фактори способу життя, такі як паління тютюну, вживання алкоголю, недостатня фізична активність, висококалорійна дієта та ожиріння.
До агентів, що можуть викликати це захворювання, належать застосування комбінованих естроген-прогестеронових контрацептивів та естрогенпрогестеронової терапії у період менопаузи, х- та $\gamma$-радіаційні промені.

Припускають, що генетичний фактор дає внесок 5-10\% у захворюваність на РМЗ, решта зумовлена факторами, які можна попередити [6-8].

Більший рівень захворюваності на РМ3 серед населення урбанізованих регіонів порівняно 3 сільськими, зростання захворюваності серед жінок із країн Азії після переселення у США свідчать про певне значення у розвитку захворювання також факторів довкілля [1, 2, 4, 6].

Доведено, що естрогенні гормони, крім здійснення фізіологічних функцій, за певних обставин можуть бути задіяні у розвитку РМЗ [1, 2, 4, 6, 9]. Як відомо, ці гормони відіграють важливу роль у процесах росту, розвитку та функціонування молочної залози (МЗ) протягом усього життя. Вони представлені групою ліпофільних структурно подібних стероїдних гормонів, попередниками яких $є$ холестерол [7, 10, 11]. У результаті низки біохімічних реакцій холестерол трансформується у стероїдний гормон андроген, який потім за участі ферменту ароматази конвертується в естрогенні гормони - естрон (E1) та естрадіол (Е2).

В організмі людей і тварин естрогени, як і інші гормони, діють як сигнальні молекули і виробляються у жіночих (яєчниках) та у чоловічих (яєчках) статевих залозах, а також у невеликій кількості у наднирниках, головному мозку та жировій тканині у представників обох статей.

Естрадіол виробляється у людей і тварин у найбільшій кількості і є найбільш активним природним гормоном, ідентичним в усіх хребетних.

Синтез і секреція естрогенів мають циклічний характер і залежать від функціонального стану репродуктивної системи.

У жіночому організмі найбільша кількість естрогенів (Е1 та E2) в умовах норми продукується у доменопаузний період.

Відповідно до сучасних поглядів естрогенні гормони здійснюють свою фізіологічну функцію шляхом зв'язування та активації відповідних їм ядерних естро- генних рецепторів (ЕР) у тканинах-мішенях i таким чином впливають на функціонування клітин. Тобто естрогени $€$ природними ендогенними лігандами ЕР. Експресія рецепторів відбувається у клітинах усіх органів жіночої репродуктивної системи, зокрема у МЗ $[7,10]$.

Естрогени можуть діяти як активні мітогени, тобто стимулювати проліферацію клітин. В умовах норми мітотичний ефект естрогенів обмежується дією прогестерону.

Незважаючи на доведене прогностичне значення рівня ендогенних естрогенів для визначення ризику РМЗ залишаються до кінця не з'ясованими механізми його ініціації. Згідно з однією із гіпотез більшість випадків захворювання виникає із малодиференційованих стовбурових клітин кінцевих зачатків термінальних протоків МЗ. Проліферація цих клітин та збільшення їхньої кількості сприяе збільшенню ризику злоякісно трансформації. Ці клітини містять рецептори і чутливо реагують на дію естрогенів. У процесі задіяні також шляхи естрогенів яєчників, які передають сигнали через рецептори гормонів. Завдяки проліферації клітин кінцевих зачатків збільшується довжина протоків та їх деревоподібне розгалуження 3 кожним менструальним циклом. Не виключається можливість прямої генотоксичної дії естрогенів на МЗ та індукції анеуплодії $[1,12]$.

Дані останніх років вказують на важливу роль міжклітинних зв'язків та взаємодії клітина міжклітинне середовище. Морфогенез тканини МЗ включає багато реципрокних (зворотних) взаємодій між стромою та епітелієм, які регулюються естрогенними гормонами. Викривлення цих взаємодій призводить до порушень на клітинному рівні, що дають поштовх до малігнізації [13].

Чутливість МЗ до дії естрогенів і їхній можливий вплив на зростання частоти РМЗ чітко продемонстрував сумний приклад медичного застосування синтетичного естрогену діетилстильбестролу (ДЕС). ДЕС діє подібно до природного естрогену. Він широко використовувався у 1940-1970-х роках для попередження спонтанних абортів та лікування інших ускладнень вагітності, лікування симптомів менопаузи, у складі оральних контрацептивів, а 


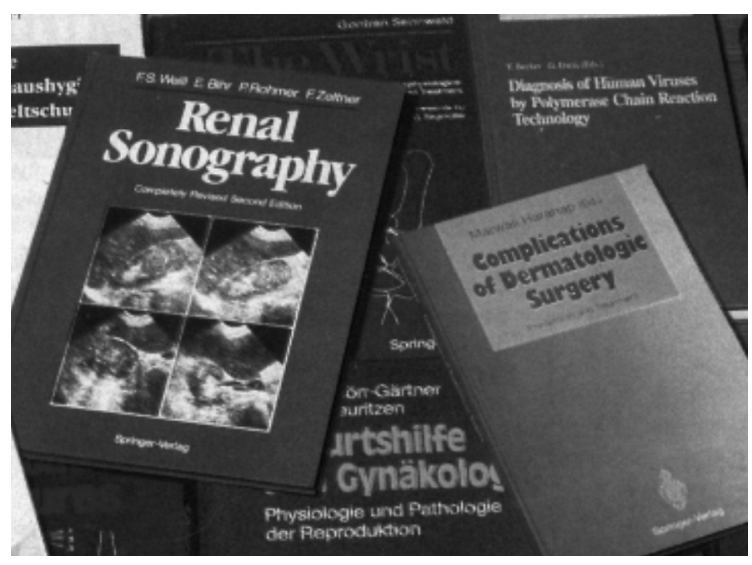

також для лікування раку простати. ДЕС навіть призначали новонародженим для збільшення приросту маси тіла [3, 6, 7, 14]. Використання ДЕС було різко обмежене і заборонене після повідомлення у 1971 році про збільшення захворюваності на РМЗ і розвиток рідкісної форми вагінальної аденокарциноми серед молодих жінокматерів, яких лікували ДЕС у період вагітності [15]. За деякими даними, за 1940-1970 роки до 10 млн. жінок (матерів та їхніх дочок) були експоновані ДЕС. Із них близько 3 млн. жінок були експоновані у США, решта - у Канаді, Об'єднаному Королівстві та інших країнах Європи, а також в Австралії та Новій Зеландії [4, 7].

Важливо відзначити, що в епідеміологічних дослідженнях жіНок, яких лікували ДЕС під час вагітності, встановлено помірне зростання захворюваності на РМЗ [16], тоді як тривале дослідження захворюваності на РМЗ серед дочок (4653 особи) таких жінок, проведене у США, показало більш суттєве зростання захворювань порівняно $з$ їхніми матерями $[9,17]$.

Більша захворюваність на РМЗ серед дочок порівняно 3 матерями вказує, що експозиція ДЕС у ранній період життя (внутрішньоутробний) збільшує чутливість до захворювання на РМЗ. Надзвичайно важливо, що отримані результати довели критичну роль у виникненні РМЗ експозиції ДЕС у ранні періоди розвитку або у так звані чутливі "вікна", коли МЗ $є$ найбільш чутливою до дії гормонів.

Експериментальні дослідження експозиції ДЕС на гризунах (мишах, щурах, хом'ячках) підтвердили ці закономірності [14]. За дії ДЕС зростають кількість пухлин МЗ та їхня множинність (кількість пухлин на одну тварину) і/або ступінь їхньої злоякісності. Ці дослідження показали, що рання експозиція ДЕС посилює також чутливість до дії інших канцерогенних сполук. У досліді на мишах неонатальна експозиція ДЕС викликала тривалі стійкі порушення процесів проліферації та диференціювання у МЗ, які спостерігалися у дорослих тварин.

Посилаючись на інших авторів, Fenton S.E. et all [14] висловлюють припущення, що можливими механізмами, які лежать в основі довічних ефектів внаслідок дії ДЕС у внутрішньоутробний період, можуть бути експериментально встановлені епігенетичні порушення, такі як зміна експресії ферменту ДНК-метилтрансферази та порушення метилювання ділянки промотора генів-мішеней естрогену, що контролюють апоптоз клітин, модифікація гістонів і виключення експресії специфічних мікро-РНК.

Ha думку Gibson D.A. та Saunders P.T.K. [7], одним 3 правдоподібних молекулярних механізмів розвитку пізніх ефектів ДЕС $є$ виявлене в експонованих in utero мишей порушення експресії гена із сім'ї HOX, які пов'язані з процесами росту і розвитку. На користь цього свідчать дані про те, що ДЕС викликає посилення метилювання гена HOX і зростання експресії ДНК-трансфераз, що призводить до зміни експресії гена HOX і може свідчити про епігенетичні механізми порушення програмування розвитку M3 [18].

Аналіз наявних даних вказує на подібність проявів дії ДЕС у людей і лабораторних тварин, що дало підставу для припущення і про схожість механізмів [6, 7, 19]. Більш того, ці дані з урахуванням доведеної можливості наслідування нащадками фенотипів захворювань, індукованих ендокринними дизрапторами за умови експозиції in utero [8], викликають занепокоєння з приводу можливого збільшення ризику РМЗ також серед нащадків наступних поколінь [4]

Докази зв'язку естрогенів 3 розвитком РМЗ були підставою для припущення щодо можливої ролі хімічних забруднень з властивостями ендокринних руйнівників (XPEC), яке сприяло активації проведення досліджень у цьому напрямку.

Нині проведено численні епідеміологічні та експериментальні дослідження in vitro та in vivo.

З великої кількості ендокринних дизрапторів найбільш часто досліджуваними залишаються стійкі біокумулятивні хлорорганічні сполуки - хлорорганічні пестициди, зокрема дихлордифенілтрихлоретан (ДДТ), поліхлоровані біфеніли (ПХБ) та діоксини, які відрізняються за профілем активності. При цьому вони можуть діяти як агоністи, тобто аналогічно гормонам специфічно зв'язуватися з рецепторами гормонів і викликати такі ж біоефекти, як і ендогенні гормони. Ці сполуки можуть зв'язуватися з гормональними рецепторами, але діагностовані зміни не $€$ схожими з ефектами, індукованими природними гормонами, внаслідок блокування їхньої дії. Отже, вони діють як антагоністи природних гормонів.

Загалом стійкі органічні сполуки не є класичними канцерогенами для МЗ, оскільки не проявляють чіткої генотоксичності і не викликають розвитку пухлин у стандартних дослідах на гризунах [20]. Проте вони можуть сприяти розвиткові РМЗ через порушення розвитку залози та її реакцій у відповідь на дію гормонів, особливо за експозицій у ранні періоди життя.

Вони можуть стимулювати ріст пухлин через шляхи, опосередковані естрогеном та прогестроном, як це спостерігалося при застосуванні гормонозаміщувальної терапії [21, 22].

Деякі стійкі хімічні ХРЕС зв'язують арилвуглеводневий рецептор (AhR), який є ядерним транскрипційним фактором, що впливає на експресію генів, кодуючих ферменти метаболізму та сигнальні шляхи гормонів [23]. Стійкі органічні дизраптори накопичуються у жировій тканині, визначаються у плазмі та сироватці крови.

Діоксини, ПХБ та хлорорганічні пестициди фактично є сумішшю споріднених хімічних сполук, які відрізняються біологічною активністю та метаболічним напівперіодом виведення із організму [6].

Вважають, що концентрації їх у крови можуть відображати 
джерело їхньої експозиції, а також індивідуальну відмінність метаболізму. Кожна категорія цих сполук має конкретні механізми дії, які можуть відрізнятися від механізмів дії інших XРЕС. Тому важливо розглянути механізми, виявлені для кожної групи, і їхні можливі зв'язки 3 розвитком РМЗ.

Найбільш вивченим є ДДТ один з представників хлорорганічних пестицидів (ХОП), які широко використовувалися 3 1940-х років і були заборонені або поступово обмежені у 19701980-х роках, проте все ще виявлялися у крови, сечі та зразках елементів довкілля. Як вказано в оглядах [6, 24], за рекомендацією ВОО3 ДДТ застосовували у країнах Азії та Африки для боротьби 3 переносниками малярії, інші пестициди (ліндан, дикофол) використовували проти поширення педикульозу, для обробки плантацій бавовника, фруктових врожаїв.

В експериментах in vitro та in vivo на лабораторних тваринах ХОП проявляють різну активність впливу на ендокринну систему.

Вже доведено естрогенні властивості ДДТ та його метаболітів, показано їхню здатність зв'язувати естрогенні рецептори та індукувати зміни експресії генів, залежних від ЕР $[6,7,19]$.

Згідно з повідомленням [6] ДДТ та інші ХОП індукують також СҮР-ферменти (цитохром P450), які опосередковують метаболізм естрогенів та інших токсикантів. У деяких роботах показано, що ХОП можуть проявляти адитивний ефект in vitro на проліферацію клітин РМЗ людини на рівні низьких доз.

Виявлено також специфічні морфологічні зміни у МЗ. Так, у дорослих щурів, експонованих ДДТ у пубертатний період та протягом гестації, спостерігалися гістоморфологічні зміни у МЗ, які проявлялися проліферацією клітин епітелію термінальних структур протоків, диференціюванням та утворенням альвеолярних та тубулярних структур і свідчили про порушення нормального розвитку залози. Встановлені у щурів ефекти були підставою для припущення про можливу роль ДДТ у збільшенні ризику РМЗ у людей.

Недавно у результаті проведення унікального дослідження "випадок - контроль" було підтверджено, що експозиція in utero ДДТ пов'язана зі зростан- ням ризику РМЗ у жінок у дорослому віці [25, 26]. Спостереження тривало протягом 50 років і включало дані щодо рівнів ДДТ у плазмі крови на час внутрішньоутробної експозиції. у результаті було виявлено зв'язок ризику РМЗ з пренатальним та перинатальним впливом ДДТ. Вимірювання концентрацій пестициду у сироватці, проведені у різних містах Європи та Америки вже після заборони ДДТ, показали швидке зниження рівня самої речовини ДДТ і значно повільніше зниження у довкіллі його метаболіту - ДДЕ. У першій когорті задіяних у дослідженні осіб (20 500 дітей та молодих жінок), експонованих у 1945-1960 роки при спостереженні протягом наступних 60-ти років ризик розвитку РМЗ коливався як функція віку дітей на час експозиції у 1945 р. і концентрації ДДТ у крови у 1960 р. Ризик був у 5 разів вищим за високих концентрацій ізомера р,рґ-дДт, але лише у дівчаток, експонованих у віці до 14 років. Експозиція ДдТ після статевого дозрівання (20 років) не збільшувала ризик. У другій когорті з 20700 вагітних жінок виявлено, що експозиція матерів Ддт у 1959-1967 роках призвела до зростання через 50 років ризику РМЗ серед 9300 дочок, який був у 5 разів більшим порівняно з дітьми неекспонованих матерів, але цей ефект спостерігався тільки у випадках високих концентрацій ізомера о,рґ-Ддт. РМЗ був естроген-рецепторно позитивним (ER+) та прогестрон-рецепторно позитивним (ПР+) відповідно у $83 \%$ та $76 \%$ випадків. У випадках високих рівнів о,рґ-ДДТ у матерів відзначено також розвиток пухлин, рецепторно позитивних щодо епідермального фактора росту людини (HER2+).

Незважаючи на безперечні докази критичної ролі ранньої експозиції ДДТ у розвитку РМЗ дотепер незрозумілими залишаються механізми, за допомогою яких ця сполука програмує залозу на розвиток захворювання у дорослому житті [14]. Як вже було зазначено, Cohn B.A. et all [26] у своєму дослідженні встановили достовірний зв'язок між рівнями о,рґ-ДДТ у сироватці крови матерів під час вагітності і зростанням розвитку HER 2+ РМЗ в їхніх дочок. 3 урахуванням цього факту і даних in vitro та in vivo щодо змін, пов'язаних 3 епідермальним фактором росту, автори перед- бачають, що порушення сигнальних шляхів цього фактора у ранній період - один з елементів розвитку РМЗ у дорослих дочок [14].

Зв'язок експозиції дДТ у ранній період життя з захворюваністю дорослих жінок на РМЗ підтверджують недавно опубліковані результати оцінки часового розподілу смертності жінок через РМЗ на Тайвані [27]. Встановлено найвищі рівні смертності серед жінок, які народилися 1951 року, що збігається з періодом максимального використання ДДт для попередження захворювань на малярію.

Цікавими є дослідження, присвячені вивченню інших ХОП [6]. Проведений мета-аналіз робіт за 1996-2006 роки показав значно вищі середні геометричні рівні гептахлору серед жінок 3 захворюванням на РМЗ порівняно 3 контролем і зростання надлишку РМЗ серед жінок 3 більш високими рівнями у крови пестициду альдрину.

у декількох дослідженнях встановлено позитивний зв'язок між експозицією гексахлорциклогексану і розвитком РМЗ, експозицією гексахлорбензолу розвитком ЕР+ субтипів РМЗ.

Як зазначалося вище, до стійких хлорорганічних забруднювачів належать також діоксини.

Діоксини - це суміш споріднених хімічних сполук, які утворюються при спалюванні відходів виробництва та сміття, що містять хлор, а також у результаті виробничих процесів, в яких задіяний хлор, у тому числі виробництво пестицидів, відбіленого паперу, полівінілхлориду тощо. Населення зазнає впливу діоксинів переважно через споживання забруднених харчових продуктів (молока, яєць, жирного м'яса та риби), води, а також через вдихання пилу, забрудненого повітря.

Багато діоксинів є високотоксичними, але найбільш небезпечним $\in 2,3,7,8$ тетрахлордібензо-пара-діоксин (ТХДД). Ця сполука широко розповсюджена і стійка у навколишньому середовищі, характеризується високою біокумуляцією у живих організмах, особливо у жировій тканині, і повільно виводиться (період напіввиведення становить близько 30 років) [28].

За класифікацією МАВР, діоксин належить до сполук, канцерогенних безпосередньо для людей [29], але не є генотоксичним, а його канцерогенність 
INCIDENCE OF BREAST CANCER AND ROLE OF ENVIRONMENTAL PERSISTENT

ORGANOCHLORINE POLLUTANTS

(ANALYSIS OF LITERARY DATA)

Chernychenko I.O., Balenko N.V., Lytvychenko O.M., Babii V.F., Glavachek D.O., Kondratenko O.Ye.

SI "O.M. Marzieiev Institute for Public Health, National Academy of Medical Sciences of Ukraine", Kyiv, Ukraine

Background: Nowadays, breast cancer is the most common hormone-dependent cancer among women worldwide. Etiology of breast cancer is multifactoriallThe environmental endocrine disrupting chemicals (EDCs), including persistent organochlorine pollutants, are one of supposed factors for the increase of the incidence of breast cancer.

Objective: We analyzed the literary data concerning the role of some persistent organochlorine chemicals such as DDT, dioxins and polychlorinated biphenyls in breast cancer formation.

Results: The analysis of the epidemiological studies, despite their small number, demonstrates clearly the relationship of the exposure of studied endocrine disruptors with an increased risk of breast cancer in women. It has been established that exposure of EDCs during critical time periods (in utero, neonatal and pubertal), when hormones affect cell differentiation and tissue development, can disrupt the development of breast tissues and lead to the appearance of breast cancer in adult women. The results of the analysis confirm the relevance of the problem and the need in further research and solution of the issues of the population's protection from the harmful effects of endocrine disruptors.

Keywords: breast cancer, incidence, persistent organochlorine pollutions. пояснюють оксидативними ефектами та порушеннями гормональних шляхів, пов'язаних 3 процесами проліферації та апоптозу.

Механізми реалізації ефектів діоксину до кінця залишаються не з'ясованими. Водночас багато досліджень вказують, що більшість його ефектів проявляється опосередковано через арилвуглеводневий рецептор (AhR), який входить до сім'ї транскрипційних факторів [6, 7, $19,30]$. Типово AhR перебуває у цитоплазмі клітини у вигляді комплексу 3 протеїном (HSP 90). Після зв'язування з лігандом рецептор транслокується в ядро, відділяється від протеїну і утворює гетеродимери з AhR ядерним транслокатором.

Цей комплекс у подальшому зв'язується з певними елементами у складі ДНК, які реагують на AhR, що призводить до порушення транскрипції генів-мішеней, які кодують ферменти метаболізму цитохрому P-450. Проте діоксини здатні порушувати також сигнальні шляхи естрогенів шляхом перешкод на перехресних сигнальних шляхах естрогенного рецептоpa (ER) та AhR (ER-AhR), таким чином пригнічуючи ефект естрогенів.

Досліди на гризунах показали суперечливі результати залежно від експозиції у різні періоди життя. Так, за дії у періоди розвитку (ембріональний та пубертатний) виявлено затримку проліферації та диференціації у МЗ гризунів, які спостерігалися навіть у статевозрілому віці.

За результатами аналізу Fenton S.E. et all [14], порівняльні дослідження експозиції діок- сину на розвиток МЗ на потомках щурів трьох різних ліній показали значні та стійкі аномалії розвитку МЗ за дії однократної дози діоксину у період розвитку зачатків МЗ. Ефекти проявлялися зменшенням розгалуження протоків, затримкою міграції епітелію у жирові прошарки та зниженням диференціювання зачатків термінальних протоків залози.

Виявлено, що ефекти регулювалися сигналами із стромального компонента залози. Крім того, зміни, індуковані у ранній період, збільшують чутливість тварин, тобто подовжують "вікно" чутливості до наступної дії субканцерогенних доз хімічного канцерогену. У результаті спостерігається збільшення частоти пухлин МЗ та скорочення латентного періоду їхнього розвитку.

Водночас експозиція статевозрілих щурів, навпаки, призводить до зниження частоти пухлин МЗ та їх метастазування, що пояснюється антиестрогенною дією діоксину через перешкоди у шляхах ER-AhR

Важливо зазначити, що виявлені закономірності в експерименті збігаються 3 даними епідеміологічних досліджень, проведених в Італії після хімічної катастрофи (м. Seveso, 1976 р. $[31,32])$. Визначення рівнів ТХДД у крови було проведено у жінок різного віку (від 0 до 40 років на час аварії), які мешкали у найбільш забруднених районах. Більшість зразків крови було відібрано протягом року після аварії, 9\% - за 2-21 рік. Виявлено, що напівперіод виведення ТХДД становить 5-10 років у дорослих:,менш корот- кий - у новонароджених та дітей.

Встановлено більшу частоту захворювань РМЗ серед жінок 40-річного віку, які були дітьми на час аварії, порівняно з жінками, які тоді були дорослими.

Припускається, що антиестрогенні властивості діоксину відіграють роль протектора для дорослих жінок, тоді як рання експозиція, що відповідає критичним "вікнам", призводить до розвитку РМЗ [31, 32].

Ці дослідження викликають також інтерес у зв'язку з тим, що діоксини були основним компонентом забруднення, тому такий розвиток РМЗ фактично пов'язаний переважно з впливом ТХДД, а не суміші.

Шкідливий вплив діоксину за дії у ранній період життя було підтверджено також при проведенні спеціального спостереження за пубертатним розвитком когорти 200 бельгійських дівчат-підлітків (віком 15,8-19,6 років). При цьому виявлено затримку розвитку M3, що була пов'язана зі збільшенням рівнів діоксину за результатами вимірювання у сироватці крови [33]. На аналогічні порушення розвитку МЗ у підлітків вказують також інші автори [14].

Як було зазначено, до стійких хлорорганічних забруднювачів також належать поліхлоровані біфеніли (ПХБ) - група хімічно стійких споріднених ароматичних сполук (209 сполук) з різними типами заміщення хлором. Вони використовуються у виробництві електричного обладнання, пластичних смол, безкарбонатного копірувального паперу тощо. 
Забруднення навколишнього середовища і ризик для здоров'я були підставою для заборони їх використання, проте понад 70\% виробленої кількості ще продовжували використовувати довго після заборони [30].

ПХБ $є$ забруднювачами довкілля і виявляються у жирних харчових продуктах (м'ясі, рибі), у повітрі приміщень, пилових забрудненнях від замазок, будівельних матеріалах, покриттях підлоги, які містять ці сполуки.

ПХБ - жиророзчинні сполуки, біокумулятивні, напівперіод виведеннями із організму становить 3-15 років, більш тривалий - для сполук з більшим ступенем хлорування. Склад суміші ПХБ у крови відображає джерело забруднення (харчові продукти, забруднене приміщення чи професійна експозиція). За класифікацією МАВР ПХБ є ймовірними канцерогенами для людей (група 2А) [34].

Механізми дії ПХБ залишаються маловивченими. Проте результати досліджень свідчать про різні шляхи реалізації ефектів ПХБ на організм.

Наприклад, деякі ПХБ (ПХБ$126,118)$ та комерційні суміші (Араклор 1260, 1254; Кенехлор 500) проявляють діоксиноподібну активність і зв'язуються 3 AhR-рецептором. Інші споріднені сполуки, так звані конгерени та їхні метаболіти мають різну, пов'язану з раком активність: стимулюють розвиток пухлин, проявляють естрогенну активність та індукують ферменти цитохрому - P450 [34]. Індивідуальна відмінність метаболізму ПХБ, як наприклад, генетичний варіант ферменту CYP1A, може вести до зростання канцерогенно активних метаболітів ПХБ, що, у свою чергу, впливатиме на відповідь організму на їхню дію [35]. Встановлено, що гідроксиметаболіти $\epsilon$ більш естрогенно активними, ніж вихідні сполуки.

Канцерогенний ефект ПХБ може бути пов'язаним також 3 їхньою здатністю активувати ендотеліальні клітини, індукувати розвиток процесів, що сприяють метастазуванню, таких як збільшення проникності судинного ендотелію, індукція молекул адгезії [30].

Доведено, що багато ПХБ індукують ДНК-адукти та утворюють оксидативні метаболіти, які можуть ушкоджувати ДНК [6].

Епідеміологічні дослідження показали різні результати впливу ПХБ на МЗ залежно від способів дії: через активацію AhR, естрогенного рецептора (ЕР) чи індукцію ферментів цитохрому P-450.

Так, у деяких дослідженнях виявлено позитивний зв'язок ПХБ, ідентифікованих як індуктори ферменту CYP $1 \mathrm{~A} / 2 \mathrm{~B}$, які здатні підсилювати також токсичність інших хімічних сполук та порушувати рівень гормонів.

У роботі, проведеній за програмою «Дослідження здоров'я і розвитку дітей» [36], визначали рівень ПХБ у крови жінок, які народилися у 1959-1967 роках (період пікового використання ПХБ), і спостерігали за ними до досягнення 50-річного віку. Особливість роботи полягає у тому, що експозиція ПХБ охоплює період вагітності, найбільш уразливий для плоду період, коли відбувається інтенсивна проліферація і диференціювання клітин у МЗ за умов нормального перебігу вагітності.

При цьому аналіз окремих представників ПХБ показав 6кратне зростання додаткового ризику РМЗ серед жінок, що зазнали найвищої експозиції ПХБ 203, порівняно з мінімально експонованими жінками.

В інших дослідженнях виявлено позитивну асоціацію усієї групи СҮР-індукуючих ПХБ 3 розвитком РМЗ та окремими субтипами пухлин.

За даними мета-аналізів, достовірно позитивний зв'язок встановлено між додатковим ризиком РМЗ і окремими СҮРіндукторами - ПХБ 99 та ПХБ 183 [37], а також між групою СҮР-індукторів і окремими сполуками ПХБ (ПХБ 99, 153, 180, 183 та 203) [38].

Низка робіт була присвячена вивченню ПХБ з естрогенними та діоксиноподібними властивостями [6]. Додаткове зростання РМЗ виявлено серед жінок у постменопаузний період, яке було пов'язане 3 дією естрогенних ПХБ, встановлено позитивний зв'язок 3 естрогенним ПХБ 187 [37].

В іншому мета-аналізі показано позитивний зв'язок між зростанням ризику PM3 і дією AhRактивної групи ПХБ [38]. При вивченні впливу AhR-активного ПХБ 167 і естрогенного ПХБ 187 виявлено захисний ефект [36]. При дослідженні впливу комплексу ПХБ, що містив більш високу пропорцію ПХБ 203 (СҮР-активний) у комбінації 3 ПХБ AhR-активним 167 та естрогенноактивним ПХБ 187 , встановлено зростання ризику РM3 [36].

Ці дані свідчать про коливання ефектів залежно від часу експозиції ПХБ, їхнього складу та співвідношення у комплексі, який містить ПХБ з різною біологічною активністю та властивостями.

Rodgers K.M. et all [6] на основі проведеного огляду досліджень щодо зв'язку між дією ПХБ і розвитком РМЗ дійшли висновку, що зростання ризику РМЗ має місце серед жінок 3 певним генетичним варіантом цитохрому P-450 (CYP1A1), що має важливе значення, оскільки ці ферменти впливають на метаболізм як ПХБ, так і ендогенних гормонів.

Поодинокі дослідження вказують на вплив професійної експозиції ПХБ [39]. Показане зростання частоти захворювань РМЗ серед чоловіків, які зазнали впливу на робочому місці ПХБ у комбінації з діоксином на рівнях вище середніх.

Вплив забруднень навколишнього середовища, у тому числі XРEC, на виникнення РМЗ було показано у недавно проведеному натурному дослідженні в Італії [40]. Автори вивчали захворюваність населення на гормонозалежні пухлини на 14 територіях країни, які характеризувалися наявністю великих промислових об'єктів, полігонів та звалищ промислових і побутових відходів, які $€$ джерелами забруднення XРEC.

У навколишньому середовищі досліджуваних територій було ідентифіковано сполуки з властивостями ХРЕС, зокрема поліхлоровані біфеніли, діоксини, важкі метали, розчинники, пестициди тощо. Найчастіше забруднення мали характер сумішей різних хімічних сполук. У результаті встановлено статистично достовірне зростання захворюваності на РМЗ, яке спостерігалося найчастіше - на 8 територіях з 12 досліджених, разом зі зростанням інших форм раку (передміхурової та щитоподібної залоз, яєчок).

Отже, ми провели аналіз літературних даних, які стосувалися ролі у формуванні РМЗ численної загалом групи стійких хлорорганічних сполук, але водночас дуже малої групи сполук з розряду ендогенних руйнівників, які мають достатньо тривалий період застосування та характеризуються широким спектром джерел їх утворення та розпов- 
сюдженням. Останнє зумовило наявність значного популяційного ризику впливу на населення. У результаті отримано беззаперечні дані щодо їхньої небезпеки.

3 наведеного огляду можна також стверджувати, що стійкі хлорорганічні забруднювачі впливають за дії малих доз і концентрацій, ефекти зростають за умов дії на організм у внутрішньоутробний та пубертатний періоди розвитку організму, ефект дії на материнський організм може передаватися нащадкам тощо. Усе це свідчить про небезпеку такого класу сполук та характеризує їх як ендокринні дизраптори.

На жаль, у наш час коло речовин, що належать до ендокринних руйнівників, значно розширилося i, зважаючи на вже відомі результати, проблеми впливу такого роду сполук $€$ вкрай актуальними і потребують негайного вивчення та розробки заходів запобігання їхньої дії на населення.

\section{REFERENCES}

1. WHO/UNEP State of the Science of Endocrine Disrupting Chemicals. 2012: An Assessment of the State of the Science of Endocrine Disruptors Prepared by a Group of Experts for the United Nations Environment Programme (UNEP) and WHO. URL:

http://www.who.int/ceh/publications/endocrine/en/

2. World Cancer Report / B.W. Stewart, C.P. Wild (eds.). Lyon : IARC Press; 2014: 630 p.

3. Rochefort H. Comptes Rendus Biologies. 2017 ; 340 (9-10) : 439-445.

4. Wael M. Abdel-Rahman, Yasser M. Moustafa, Bassamat $O$. Ahmed and Randa M. Mostafa. Asian Pac. J. Cancer Prev. 2012 ; 13 (12) : 5937-5946.

5. Gore A.C., Chappell V.A. Fenton S.E., Flaws J.A., Nadal A., Prins G.S., Toppari J. and Zoeller R.T. Endocr. Rev. 2015 ; 36 (6) : 593-602.

6. Rodgers K.M., Udesky J.O., Rudel R.A. and Brody J.G. Environ. Res. 2018 ; 160 : 152-182.

7. Gibson D.A. and Saunders P.T.K. Endocr.-Relat. Cancer. 2014 ; 21 (2) : 13-31.

8. Skinner M.K., Manikkam M. and Guerrero-Bosagna C. Reprod. Toxicol. 2011 ; 31(3) : 337-343.

9. Palmer J.R., Wise L.A., Hatch E.E., Troisi R, TitusErnstoff L., Strohsnitter W., Kaufman R., Herbst A.L. et all Cancer Epidemiol. Biomark. Prev.
2006 ; 15 (8) : 1509-1514.

10. Karoutsou E., Karoutsos P. and Karoutsos D. J Clin

Epigenetics. 2016 ; 2 (4). doi: 10.21767/2472-1158.100033

11. Ingre-Khans E., Ager-

strand M. and Ruden C.

Endocrine Disrupting Chemicals

in the Marine Environment.

Report № 16. Department of

Environmental Science and

Analytical Chemistry (ACES).

Stockholm University, 2017. 11 p.

12. Rachon D. Rev. Endocr. Metab. Disord. 2015 ; 16 : 359-364.

13. Soto A.M. and

Sonnenschein C. BioEssays.

2011 ; 33 (5) : 332-340.

14. Fenton S.E. and Birnbaum L.S. J Clin Endocrinol Metab. $2015 ; 100: 3245-3250$.

15. Herbst A.L., Ulfelder H. and Poskanzer D.C. New England Journal of Medicine. 1971 ; 284 : 878-881.

16. Greenberg E.R., Barnes A.B., Resseguie L., Barrett J.A.,

Burnside S., Lanza L.L. et all. N Engl J Med. $1984 ; 311$ : 1393 1398.

17. Hoover R.N., Hyer M.,

Pfeiffer R.M., Adam E., Bond B.,

Cheville A.L. et all. N. Engl. J.

Med. 2011 ; 365 : 1304-1314.

18. Bromer J.G., Wu J., Zhou Y. and Taylor H.S. Endocrinology. 2009 ; 50 : 3376-3382.

19. Del Pup L., Mantovani A.,

Cavaliere C., Facchini G., Luce A.

Sperlongano P., Caraglia M. and

BerrettaM. Oncol. Rep. 2016; 36

(2) : 603-12.

20. Rudel R.A., Fenton S.E.,

Ackerman J.M., Euling S.Y. and

Makris S.L. Environ. Health

Perspect. 2011 ; 119 : 10531061.

21. Rudel R.A., Ackerman J.M., Attfield K.R. and Brody J.G.

Environ. Health Perspect. 2014 ; 122 (9) : 881-895.

22. Lee H.R., Hwang K.A.,

Nam K.H., Kim H.C. and

Choi K.C. Chem. Res. Toxicol.

2014 ; 27 : 834-842.

23. NTP 2016. Report on

Carcinogens, 14-th Edition.

Research Triangle Park, NC:

United States National Toxicology

Program. URL : http://ntp.niehs. nih.gov/go/roc 14.

24. Li X., Gao Y., Wang J., Ji G., Lu Y., Yang D., Shen H., Dong Q.,

Pan L. et all. J Public Health

Emerg. $2017 ; 1$.

doi:10.21037/jphe.2016.12.09

25. Cohn B.A. Reprod. Toxicol. 2011 ; 31 : 302-311.

26. Cohn B.A., La Merrill M. Krigbaum N.Y., Yeh G., Park J.S., Zimmermann L. and Cirillo P.M. J Clin Endocrinol Metab. 2015 ;
100 (8) : 2865-2872.

27. Ho M-L., Hsaio Y-H., Su S-Y. Chou M-C. and Liaw Y-P. J Obstet Gynecol. 2015 ; 35 : 60-63.

28. Reznikov A.G. Репродуктивная эндокринология. 2014 ; 3 (17) :14-21 (in Russian).

29. IARC. 2012. Monographs on the Evaluation of Carcinogenic Risks to Humans. Vol. 100F. 2,3,7,8-tetrachlorodibenzoparadioxin, 2,3,4,7,8-pen-

tachlorodibenzofuran, and

3,3, 4,4 ,5-pentachlorobiphenyl.

Lyon, France: IARC. URL :

http://monographs.iarc.fr/ENG/

Monographs/vol100F/

mono100F-27.pdf.

30. Mallozzi M., Leone C., Manurita F., Bellati F. and Caserta D. Int. J. Environ. Res. Public

Health. 2017 ; 14 (3) : 334-356.

31. Warner M., Mocarelli P.,

Samuels S., Needham L.

Brambilla P. and Eskenazi B.

Environ. Health Perspect. 2011 ; 119 : 1700-1705.

32. Kerger B.D., Leung H.W., Scott P., Paustenbach D.J., Needham, L.L., Patterson Jr.D.G. et all. Environ. Health Perspect. 2006 ; 114 : 1596-1602.

33. DenHond E.D., Roels H.A., Hoppenbrouwers K., Nawrot T., Thijs L., Vandermeulen C., Winneke G., Vanderschueren D. and Staessen J.A. Environ. Health Perspect. 2002 ; 110 : 771-776.

34. Monographs on the

Evaluation of Carcinogenic Risks to Humans, Vol. 107.

Polychlorinated Biphenyls and Polybrominated Biphenyls. Lyon, France : IARC; 2016. URL http://monographs.iarc.fr/ENG/ Monographs/vol107/mono107. pdf.

35. Brody J.G., Moysich K.B., Humblet O., Attfield K.R., Beehler G.P. and Rudel R.A. Cancer. 2007 ; 109 : 2667-2711.

36. Cohn B.A., Terry M.B., Plumb M. and Cirillo P.M. Breast Cancer Res. Treat. 2012 ; 136 : 267-275.

37. Leng L., Li J., Luo X.M., Kim J.Y., Li Y.M., Guo X.M. et all. Environ. Int. 2016 ; 88 : 133-141.

38. Zhang J., Huang Y., Wang X., Lin K. And Wu K. PloS One. 2015 ; 10 (11): 11-18.

39. Villeneuve S., Fevotte J., Anger A., Truong T.,

Lamkarkach F., Gaye O., Kerbrat P., Arveux P. et all. Am. J. Ind. Med. 2011 ; 54 : 499-509.

40. Benedetti M., Zona A.,

Beccaloni E., Carere M. and

Comba P. Int. J. Environ. Res.

Public Health. 2017 ; 14 (4) : 355-366.

Надійшла до редакції 24.01.2019 